\title{
Magnesium mobility in soils as a challenge for soil and plant analysis, magnesium fertilization and root uptake under adverse growth conditions
}

\author{
A. Gransee • H. Führs
}

Received: 14 June 2012 / Accepted: 10 December 2012 / Published online: 29 December 2012

(C) The Author(s) 2012. This article is published with open access at Springerlink.com

\begin{abstract}
Background Due to its unique chemistry magnesium $(\mathrm{Mg})$ is subject to various cycling processes in agricultural ecosystems. This high mobility of $\mathrm{Mg}$ needs to be considered for crop nutrition in sustainable agricultural systems. The Mg mobility in soils and plants and its consequences for crop nutrition are understood, but recent findings in crop $\mathrm{Mg}$ uptake, translocation and physiology particularly under adverse growth conditions give new insights into the importance of $\mathrm{Mg}$ in crop production.

Scope The aim of this review is to combine the knowledge on the origin and mobility of $\mathrm{Mg}$ in soils with the role of $\mathrm{Mg}$ in plant stress physiology and recent evidence on the principles of crop $\mathrm{Mg}$ uptake. The question is addressed whether the progress made in $\mathrm{Mg}$ research, particularly on the role of $\mathrm{Mg}$ in stress physiology, makes a revision of the development of $\mathrm{Mg}$ fertilization recommendations necessary.

Conclusions New insights into Mg uptake and utilization but particularly into the role of $\mathrm{Mg}$ in increasing crop tolerance to various stresses indicate changes in the crop $\mathrm{Mg}$ demand under adverse growth conditions. Future work should incorporate these findings in
\end{abstract}

Responsible Editor: Ismail Cakmak.

A. Gransee $\cdot$ H. Führs $(\bowtie)$

$\mathrm{K}+\mathrm{S}$ KALI GmbH,

Bertha-von-Suttner-Str. 7,

34131 Kassel, Germany

e-mail: hendrik.fuehrs@kali-gmbh.com optimization of site-specific balanced fertilization programs particularly under stress conditions.

Keywords Antagonism - Carbohydrate formation and partitioning $\cdot$ Fertilization $\cdot$ Leaching $\cdot$ Stress

physiology $\cdot$ Soil and plant analysis

\section{Introduction}

Magnesium $(\mathrm{Mg})$ is an essential element for plant growth and development. The availability of $\mathrm{Mg}$ to plants depends on various factors: the distribution and chemical properties of the source rock material and its grade of weathering, site specific climatic and anthropogenic factors and, in agricultural systems, to a high degree on the agronomic management practices established at the specific production site including the cultivated crop species and crop rotation, cropping intensity and organic and mineral fertilization practice (Mikkelsen 2010; Scheffer and Schachtschabel 2002).

The importance of $\mathrm{Mg}$ in crop production was underestimated in the last decades (Cakmak and Yazici 2010). Indeed, compared to other nutrients little attention has been paid on this mineral nutrient by agronomists and scientists in the last decades. Therefore, the term 'the forgotten element' was introduced and used (Cakmak and Yazici 2010). One decisive reason for this gap in research may be that $\mathrm{Mg}$ deficiency is often not recognized in agriculture, so that there is no concrete stimulus for enhanced (research) activity in this area. Indeed, 
acute $\mathrm{Mg}$ deficiency is typically correlated with visible interveinal chlorosis and growth reduction, whereas the more frequent latent deficiency is often not visible and hardly to diagnose but negatively affects yield of crops (Cakmak and Yazici 2010).

Latent and acute $\mathrm{Mg}$ deficiencies are common phenomenons in crop production (Römheld and Kirkby 2007). A typical Mg deficiency symptom is leaf interveinal chlorosis. Development of chlorosis requires preceding degradation of chlorophyll, since $\mathrm{Mg}$ acts as central atom in the chlorophyll molecule. $\mathrm{As} \mathrm{Mg}$ is strongly bound to this molecule chlorosis appears to be a late response to $\mathrm{Mg}$ deficiency. In plants well supplied with $\mathrm{Mg}$ only about $20 \%$ of the total $\mathrm{Mg}$ is bound to chlorophyll, whereas the remaining about $80 \%$ are present in more mobile forms (Marschner 2012). Magnesium is phloem mobile and readily translocated within the plant to actively growing plant parts acting as sink (White and Broadley 2008). Consequently, due to the high mobility under $\mathrm{Mg}$ starvation $\mathrm{Mg}$ deficiency symptoms typically appear on older leaves of the plant (Bergmann 1992). As chlorosis is a late visible response to $\mathrm{Mg}$ deficiency considerable decreases in yield formation can be expected. Therefore, the diagnosis of chlorosis is not a suitable tool for diagnosis of $\mathrm{Mg}$ deficiency as basis for fertilization recommendations. There is some evidence that $\mathrm{Mg}$ plays specific roles in dry matter formation and carbon partitioning to sink organs, as under $\mathrm{Mg}$ deficiency carbohydrates accumulate in source leaves (Cakmak et al. 1994a, b; Ding et al. 2006). Therefore, an earlier response of plants to $\mathrm{Mg}$ deficiency is carbohydrate accumulation in source leaves and reduced root growth due to restricted supply of the roots with carbohydrates (Cakmak et al. 1994a, b), even though some contrasting results exist for some plant species, for example sugar beet (Hermans et al. 2004, 2005). Hence, disturbed carbohydrate partitioning may be regarded as latent deficiency which per definition also impacts yield formation.

It is assumed that the disturbed metabolite (e.g. carbohydrates and amino acids) partitioning under $\mathrm{Mg}$ deficiency is a consequence of impaired phloem loading of metabolites. When the root system as an important and heavy sink for metabolites suffers from limited carbohydrate supply the reduced root growth further enhances the risk of other nutrient deficiencies and environmental stresses (e.g. drought stress) due to less explored soil volume and, therefore, less access to soil resources (Cakmak and Kirkby 2008). This may be underlined by results of Damm et al. (2011), who recently published results on the effect of a long-term combined $\mathrm{Mg}$ and $\mathrm{K}$ fertilization on soil physical properties and root penetration of several plant species with different rooting systems. In this study the combined application of $\mathrm{K}$ and $\mathrm{Mg}$ increased the soil water content within the whole range of water retention up to the permanent wilting point (PWP). This soil physical effect was mainly attributed to K. However, in parallel to the $\mathrm{K}$-induced soil physical and water-storage changes also the rooting depth was increased, particularly for sugar beet. In view of the decisive role of $\mathrm{Mg}$ in carbohydrate partitioning the increase in rooting depth through combined $\mathrm{Mg}$ and $\mathrm{K}$ fertilization may be at least partly attributed to the $\mathrm{Mg}$ supply.

In principle there are two reasons for $\mathrm{Mg}$ deficiency to occur, absolute deficiency and cation competition. Absolute deficiency can be a consequence of (1) low $\mathrm{Mg}$ contents in the source rocks (Papenfuß and Schlichting 1979), (2) of Mg losses from the soil e.g. by mobilization and subsequent leaching (Schachtschabel 1954; Grzebisz 2011) and (3) of long-term unbalanced crop fertilization practice neglecting $\mathrm{Mg}$ depletion of soils through crop Mg removal (van der Pol and Traore 1993). Cation competition is a consequence of nutrient imbalances in soils. It is commonly known that the uptake of $\mathrm{Mg}$ is strongly influenced by the availability of other cations like $\mathrm{NH}_{4}, \mathrm{Ca}$ and $\mathrm{K}$ (Jacoby 1961; Diem and Godbold 1993; Fageria 2001; Römheld and Kirkby 2007). Nutrient imbalances in the soil can have soilborn and/or fertilization practice-associated reasons. Both deficiencies are closely interrelated and should be considered together.

In order to get information on the nutritional status of a crop and production site soil and plant analyses are carried out. In practice the challenge is to relate results of soil analysis to crop growth and phytoavailability of the respective nutrient and to correctly interpret the information for the development of recommendations. According to Kopittke and Menzies (2007) there are at least two principle methods of interpreting the cation $(\mathrm{K}$, $\mathrm{Mg}, \mathrm{Ca}$ ) soil concentrations, the sufficiency level of available nutrients (SLAN) and the basic cation saturation ratio (BCSR). The SLAN concept focuses on the availability of individual nutrients to plants, whereas the BCSR concept determines a site-specific optimal base cation saturation ratio of the CEC for all cations at the same time. Any deviation from this 'ideal' ratio would, according to the concept, lead to production losses. In 
their review Kopittke and Menzies (2007) revise the BCSR concept and conclude that 'within ranges commonly found in soils, the chemical, physical, and biological fertility of a soil is generally not influenced by the ratios of $\mathrm{Ca}, \mathrm{Mg}$, and $\mathrm{K}$ '. Indeed, recent molecular insights into the capability of plants to cope with highly variable nutrient concentrations not only externally (uptake from the substrate/soil) but also internally (ion homeostasis) (see secion 'Mechanisms of Mg uptake by crops') underlines that crops do not implicitly need a fixed base cation saturation ratio in the soil to reach a theoretic yield potential. In fact highly sophisticated and interconnected ion transport systems were evolved enabling the plant to quickly (sometimes within minutes in nutrient solution experiments) adapt to changing conditions of nutrient availability. However, despite these fundamental qualms about the suitability of the BCSR concept for recommendation development considerable amounts of soil tests are currently interpreted according to the BCSR concept in private laboratories (Kopittke and Menzies 2007). In contrast, in university laboratories soil analysis is done almost exclusively according to the SLAN concept. Nevertheless, even though base cation saturation ratios do not appear to reflect plant nutrient availability in a proper way, the individual base saturation of the CEC giving the exchange sites (according to CEC) occupied by base cations ( $\mathrm{Ca}, \mathrm{Mg}, \mathrm{Na}, \mathrm{K}$ ) may be in principle an important measure for agricultural practice as it gives important information on the potential of a production site to provide cations.

This review aims at (i) summarizing the current knowledge on soil and plant factors affecting Mg nutrition of plants, (ii) relating newest insights into $\mathrm{Mg}$ uptake and its role in plant (stress) physiology to the current methodologies of soil and plant analysis (iii) highlighting future research areas e.g. with respect to combining agronomic practice with plant physiology.

\section{Magnesium in the soil and rhizosphere}

Origin of magnesium in soils

Magnesium is the 8 th most abundant mineral element on earth (Maguire and Cowan 2002). Magnesium in soils originates from source rock material containing various types of silicates. The $\mathrm{Mg}$ content of different silicate types varies considerably (muscovite $>$ biotite $>$ hornblende $>$ augite $>$ olivine). The reason for variation in the $\mathrm{Mg}$ content is that within the silicates the $\mathrm{Al}^{3+}$ is substituted for $\mathrm{Mg}^{2+}$. This well described phenomenon causes typical permanent charge surpluses of silicates decisive for the physico-chemical properties of soils. Among silicates, carbonates (e.g. magnesite $\left[\mathrm{MgCO}_{3}\right]$ and dolomite $\left[\mathrm{MgCO}_{3} \times \mathrm{CaCO}_{3}\right]$, but also in calcite $\left[\mathrm{CaCO}_{3}\right]$ in concentrations of about 1-3\%) are substantial sources of $\mathrm{Mg}$ as well (Scheffer and Schachtschabel 2002). Due to high variation in $\mathrm{Mg}$ content of the source material the total content of $\mathrm{Mg}$ in soils varies considerably between 0.05 and $0.5 \%$ (Grimme 1991; Maguire and Cowan 2002). Differences in silicate contents of soils also explain higher $\mathrm{Mg}$ contents typically found in clay and silty soils compared to sandy soils. In extreme cases, in soils high in Mg-depleted silicates, mainly chlorites, $\mathrm{Mg}$ fixation can occur (Papenfuß and Schlichting 1979; Scheffer and Schachtschabel 2002). Magnesium bound in the interlayers of silicates is not mobile and is only released into mobile fractions through weathering processes, which is regarded as a long-termed, slow process (see also later sections). Plant available $\mathrm{Mg}$ concentrations in the soil solutions have been reported to vary between $125 \mu \mathrm{M}$ and $8.5 \mathrm{mM}$ (Barber 1995).

Factors determining the mobility of $\mathrm{Mg}$ in soils

In typical agronomically used, deep-grounded soils a considerable amount of the total soil $\mathrm{Mg}$ is bound in an exchangeable form. This fraction is characterized by reversible binding of the $\mathrm{Mg}$ to permanent and/or variable charge in soils. Whereas the permanent charge surplus in soils is a consequence of $\mathrm{Al}$ substitution (see previous section), the variable charge is provided by organo-mineral soil components. The variable charge is strongly dependent on the $\mathrm{pH}$ of soils. Both the permanent and variable charge of soils form the cation exchange capacity (CEC). Two different CECs are differentiated: (i) the potential cation exchange capacity $\left(\mathrm{CEC}_{\text {pot }}\right)$, which is determined at a soil $\mathrm{pH}$ around 77.5 and (ii) the effective cation exchange capacity $\left(\mathrm{CEC}_{\text {eff }}\right)$ measured under the actual soil $\mathrm{pH}$ underlining the high dependence of the $\mathrm{CEC}$ on $\mathrm{pH}$. In fact, the CEC can be regarded as the (potential or actual) capacity of a soil to reversibly bind or buffer cations (Mehlich 1948; Scheffer and Schachtschabel 2002).

In contrast to other cations like $\mathrm{K}, \mathrm{Ca}$, and $\mathrm{NH}_{4}{ }^{+}$ $\mathrm{Mg}$ is comparatively mobile in soils. The properties or the 'behaviour' of $\mathrm{Mg}$ in soils can be ascribed to its 
unique chemical properties. Whereas the ionic radius of $\mathrm{Mg}$ is smaller than that of $\mathrm{Ca}, \mathrm{K}$ or $\mathrm{Na}$, its hydrated radius is substantially larger (Shaul 2002; Gardner 2003; Maguire and Cowan 2002). One consequence is that $\mathrm{Mg}$ is less strong bound to soil charges (CEC) leading to compared to other cations higher $\mathrm{Mg}$ concentrations in the soil solution. This has consequences for the mobility of $\mathrm{Mg}$ in the soil and implications for plant $\mathrm{Mg}$ nutrition.

\section{Consequences of the mobility of $\mathrm{Mg}$ in soils}

Two points need to be mentioned, which appear to be the most important consequences of the high $\mathrm{Mg}$ mobility. First the high concentration of $\mathrm{Mg}$ in the soil solution explains the extraordinary high contribution of mass flow to plant $\mathrm{Mg}$ nutrition (Barber et al. 1963). The contribution of mass flow to $\mathrm{Mg}$ nutrition of crops can be calculated from the $\mathrm{Mg}$ concentration in the soil solution and the amount of water transpired by the crop. However, even though the contribution of mass flow to $\mathrm{Mg}$ nutrition compared to $\mathrm{K}$ is principally sufficient under optimum conditions (soil humidity, $\mathrm{Mg}$ concentration in soil solution) in agriculturally used soils as a consequence of the high $\mathrm{Mg}$ concentrations in soil solution (Fig. 1a, Karley and White 2009; Barber 1995), it also depends on the species-specific demand and root system of a crop species (Fig. 1b, Strebel and Duynisveld 1989; Marschner 2012). However, under adverse conditions like drought, this system of delivery to the roots can be disadvantageous as the transport of $\mathrm{Mg}$ to the roots can be impaired.

Second, $\mathrm{Mg}$ is subject to leaching in considerable amounts. Koc and Szymczyk (2003) and Grzebisz (2011) gave an overview over seasonal Mg leaching from typical soil types present in Poland. The major part is leached in autumn and winter months due to the high positive water balance. Independent of the soil type $\mathrm{Mg}$ leaching can reach up to $25 \mathrm{~kg} \mathrm{Mg} \mathrm{ha}^{-1}$. Boysen (1977) investigated nutrient leaching in different soils under different cropping systems and found that under forest ca. $9.5 \mathrm{kgha}^{-1}$ was leached, whereas under arable land ca. $20 \mathrm{kgha}^{-1}$ was lost by leaching. Another study reports $\mathrm{Mg}$ leaching from a soil of limited fertility in the magnitude of 45-70 $\mathrm{kgha}^{-1}$ depending on crop type and developmental stage, $\mathrm{N}$-fertilization, precipitation quantity and intensity and consequently the drainage volume (Mesić et al. 2007). This high variation in $\mathrm{Mg}$ leaching can be explained by the numerous factors that influence the magnitude of $\mathrm{Mg}$ leaching which include the amount of leaching water, soil acidity (the presence of $\mathrm{H}^{+}$ions), the $\mathrm{Ca}$ concentration (liming), the bicarbonate $\left(\mathrm{HCO}_{3}{ }^{-}\right)$concentration and the cation exchange capacity as affected by the clay and organic matter content. In view of NPK-dominated fertilization practice often neglecting $\mathrm{Mg}$ these $\mathrm{Mg}$ losses together with considerable $\mathrm{Mg}$ offtake with harvested plant products soil mining of $\mathrm{Mg}$ may occur frequently (Römheld and Kirkby 2007, see also later sections).

\section{Mechanisms of Mg uptake by crops}

To understand the Mg nutrition of crops knowledge on the processes involved in $\mathrm{Mg}$ uptake and uptake of other cations is necessary. Therefore, this section focuses on the physiology cation uptake with special emphasis on the question of the physiological background of $\mathrm{K}-\mathrm{Mg}$ antagonism.

An interesting phenomenon is the competition of cations for uptake (Jacoby 1961; Diem and Godbold 1993; Fageria 2001; Marschner 2012; Chen and Ma 2012) which is often experienced in agriculture under unbalanced soil nutrient composition. In nutrient solution experiments it has been shown that high availability of the cations $\mathrm{Ca}, \mathrm{K}$ and $\mathrm{Mn}$ can lead to strong decreases in Mg uptake (Marschner 2012). Fageria (1973) reported on the effect of increasing Ca concentration in a nutrient solution on the uptake of $\mathrm{Mg}$ and $\mathrm{K}$ by rice plants (Table 1). The author showed that increasing the $\mathrm{Ca}$ concentration to a certain level increases the uptake rates of $\mathrm{Mg}$ (and also $\mathrm{K}$, not displayed here). It is assumed that at very low availability of $\mathrm{Ca}$ (Ca deficiency) the plasma membranes of root cells are adversely affected leading to ion leakage and unspecific uptake. Slightly increasing the $\mathrm{Ca}$ concentration in the nutrient solution then rapidly restores the membrane functionality, so that the uptake of other cations is enhanced and leakage reduced. Further increasing the $\mathrm{Ca}$ concentrations in the nutrient solution then turns the positive synergistic effect of the nutrients into an antagonistic cation competition for uptake. This is reflected by a reduction in uptake of $\mathrm{Mg}$ (and $\mathrm{K}$ ) when the $\mathrm{Ca}$ concentration in the nutrient solution is further increased (Table 1, Fageria 1973, 2009; Marschner 2012). The picture gets even more complex when nonessential cations are included. For example de Wit et al. (2010) recently provided evidence for a specific impact of toxic $\mathrm{Al}$ ions (as released by acid depositions) on the 
Fig. 1 Contribution of root interception, mass flow and diffusion to the $\mathrm{K}$ and $\mathrm{Mg}$ demand of maize (a) and contribution of mass flow to measured uptake of $\mathrm{K}$ and $\mathrm{Mg}$ to spring wheat and sugar beet (b). Data from a Barber (1995) and b Strebel and Duynisveld (1989)

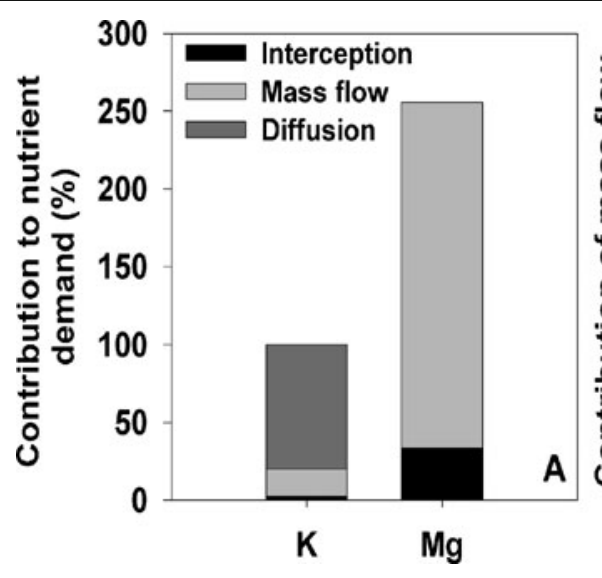

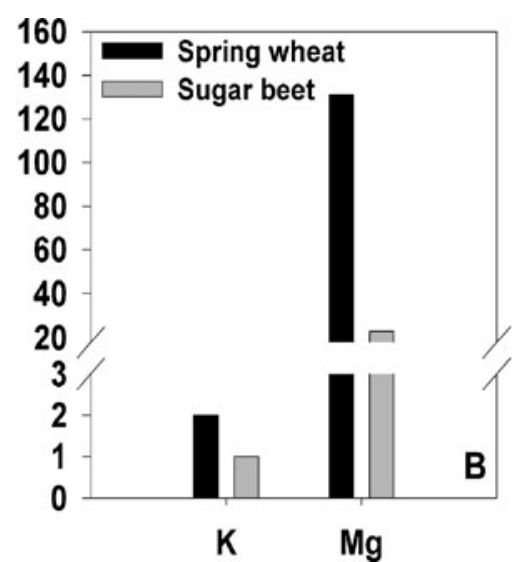

uptake of $\mathrm{Mg}$ but not $\mathrm{Ca}$ in Norway spruce. The reason for this specific antagonistic effect on $\mathrm{Mg}$ uptake is not known. However, reduced forest vitality due to $\mathrm{Al}$ excess-inhibited $\mathrm{Mg}$ uptake has implications for risk evaluations of forest health under acid deposition highlighting the importance for future research not only for agriculture.

Which are the mechanisms leading to such antagonistic effects? In the following sections some ideas are presented based on the current knowledge on cation uptake by plants and very recent results particularly on transporters involved in $\mathrm{K}$ and $\mathrm{Mg}$ uptake. Two facts may already imply the need for specific and distinct uptake systems for $\mathrm{K}$ and $\mathrm{Mg}$ in crops. First, there are differences in the hydrated ionic radius between both ions (Maguire and Cowan 2002). Even though the ionic radius of $\mathrm{Mg}$ is smaller than that for $\mathrm{K}$ the hydrated radius of $\mathrm{Mg}$ is bigger indicating the need for ion-

Table 1 Effect of increasing $\mathrm{Ca}$ concentrations in nutrient solution on uptake rates of $\mathrm{Mg}$ and $\mathrm{K}$ in rice (adapted from Fageria 1973, 2009)

\begin{tabular}{ll}
\hline Ca concentration $(\mu \mathrm{M})$ & $\begin{array}{l}\text { Mg uptake rate } \\
{\left[\mu \mathrm{g}(\mathrm{g} \text { root dry weight } * \mathrm{~h})^{-1}\right]}\end{array}$ \\
\hline 6.23 & 3.80 \\
12.47 & 5.06 \\
49.90 & 25.70 \\
74.79 & 52.59 \\
124.75 & 57.41 \\
249.50 & 62.49 \\
499.00 & 46.46 \\
748.00 & 30.76 \\
$\mathrm{R}^{2}$ & $0.66 *$
\end{tabular}

specific transport proteins. In addition, as a consequence of the different delivery mechanisms for $\mathrm{K}$ and $\mathrm{Mg}$ to the roots (mass flow versus diffusion), the concentrations of both nutrients in the soil solution typically differ that much particularly in the rhizosphere (Zhang and George 2002; Marschner 2012), that specific uptake systems are required to meet the actual crop demands. From investigations on the course of $\mathrm{K}$ uptake as a function of the $\mathrm{K}$ concentration in the substrate a socalled 'High-Affinity Transport System' (HATS) was proposed, which could describe the uptake for a specific $\mathrm{K}$ concentration range (Epstein et al. 1963; Britto and Kronzucker 2008). It has been shown that the $\mathrm{K}$ status of the plant regulates $\mathrm{V}_{\text {max }}$ of the HATS. Low plant $\mathrm{K}$ status thereby increases the $\mathrm{V}_{\max }$ by HATS and high plant $\mathrm{K}$ decreases $\mathrm{V}_{\text {max }}$. However, in their early studies Epstein et al. (1963) found that at higher external K concentrations the uptake pattern was different, as it did hardly show any saturation level. This means that $\mathrm{K}$ supply and $\mathrm{K}$ uptake showed an almost linear relationship over wide concentration ranges. For this mechanism the term 'Low-Affinity Transport System' (LATS) was established. The efficiency of the LATS is thereby modulated by the accompanying anion (Britto and Kronzucker 2008 and literature cited therein). Chloride as accompanying anion strongly increases the uptake rates as compared to sulfate and phosphate, which is most probably a consequence of a (temporarily) increased electrochemical gradient established by $\mathrm{Cl}^{-}$. In contrast $\mathrm{SO}_{4}{ }^{2-}$ and $\mathrm{H}_{2} \mathrm{PO}_{4}{ }^{-}$are metabolized or accumulated in lower amounts in the plant tissue that the electrochemical gradient remains almost unaffected.

How does the plant realize HATS and LATS? In principle three main transport systems can be distinguished, which modulate the HATS and LATS in a 
coordinated interplay: passive transport, secondary active transport and primary active transport (Marschner 2012). For passive and secondary active transport of ions across plasma membranes the work of $\mathrm{H}^{+}$ATPases is vital. These proteins form electrochemical gradients across the plasma membrane providing energy for cation transport. Passive transporters use the electrical force, whereas secondary active transporters or so-called 'coupled transporters' use the energy of the electrochemical gradient in order to co-transport (either in the same (symport) or the opposite (antiport) direction) $\mathrm{a}^{+}$ion and the nutrient ion. In contrast to the first two transport systems the primary active transporters directly use energy from energy rich compounds like ATP and couple this to the uptake of nutrients. The electrochemical gradient has no impact on this transport system. For the HATS mechanism of $\mathrm{K}$ the secondary active transport (symport) was suggested, whereas for the LATS mechanism the passive transport via channels was proposed (Britto and Kronzucker 2008). In principle the concept of HATS and LATS including the respective transport mechanisms was described for $\mathrm{K}$ but was also suggested to be present in plants for $\mathrm{Mg}$ (Shabala and Hariadi 2005).

As described there are numerous reports showing that cations can reduce $\mathrm{Mg}$ uptake, whereas to our knowledge there are very few studies available showing that $\mathrm{Mg}$ hampers the uptake of $\mathrm{K}$ or other cations to the same level. For example Scharrer and Jung (1955) showed that $\mathrm{Mg}$ fertilization of perennial ryegrass reduced the $\mathrm{Ca}$ and $\mathrm{Na}$ contents of the plants but did not affect the $\mathrm{K}$ uptake. But why does $\mathrm{K}$ affect $\mathrm{Mg}$ uptake and not or not so drastically vice versa? This phenomenon is not yet fully understood. However, from the available information it may be concluded that the observed competition for uptake is a consequence of the lack of specificity of the individual uptake systems for each cation (Gardner 2003; Shaul 2002; Deng et al. 2006; Marschner 2012). Some Mg transporters may also transport other cations like $\mathrm{K}$. As a consequence a high plant available $\mathrm{K}$ concentration in the soil/rhizosphere blocks these unspecific $\mathrm{Mg}$ transporters for $\mathrm{Mg}$ uptake. On the other hand, high $\mathrm{Mg}$ concentrations in the soil solution do not inhibit K uptake as K uptake even at low external concentrations in the soil solution is facilitated by very specific $\mathrm{K}$ transporters of the HATS which are not blocked by $\mathrm{Mg}$. For the sake of completeness it has to be mentioned that the antagonistic effect can occur not only in the roots, where the nutrients are taken up but also within the plant. It has been frequently observed that $\mathrm{Mg}$ concentrations in roots are not affected by $\mathrm{K}$ $\mathrm{Mg}$ antagonism, but the translocation from the root to the shoot is impaired by high $\mathrm{K}$. It can be suggested that similar mechanisms operate here as well.

As proof of concept very recently Horie et al. (2011) could show for two members of the class II of HKT transporters in rice, that they are principally (among $\mathrm{K}$ ) also capable of transporting $\mathrm{Mg}$ and $\mathrm{Ca}$ but that under $\mathrm{K}$ supply the uptake of these cations is hampered giving a first molecular hint for the mechanisms underlying cation competition. In addition, the data provided by Horie et al. (2011) show that the considerable differences in $\mathrm{K}$ and $\mathrm{Mg}$ chemistry, e.g. the differences in the radius of the hydrated ions, may be not sufficient to reason specific uptake systems (see discussion above). Also, Shabala and Hariadi (2005) provided evidence that Mg uptake in leaf mesophyll cells of broad bean is facilitated by two systems, a non-selective ion channel and at lower Mg concentrations by a $\mathrm{H}^{+} / \mathrm{Mg}^{2+}$ exchanger. The non-selective channel system was also capable of $\mathrm{K}$ and $\mathrm{Ca}$ transport. Provided that such transport systems also appear in root plasma membranes this is another hint that $\mathrm{K}$ and $\mathrm{Ca}$ can reduce $\mathrm{Mg}$ uptake by these non-selective ion channels. Future work is necessary to further clarify the underlying mechanisms. The interested reader on the current knowledge on molecular and physiological aspects of $\mathrm{Mg}$ nutrition and homeostasis in plants is referred to other reviews on this topic (Shaul 2002; Gardner 2003; White and Broadley 2008; Chen and Ma 2012). Other important areas of research for the future should also focus on the question on how plants react to $\mathrm{Mg}$ deficiency. Are there shoot/root-derived signals leading to physiological or morphological changes with the aim to improve $\mathrm{Mg}$ acquisition? Does the uptake kinetic for $\mathrm{Mg}$ change under $\mathrm{Mg}$ deficiency in a similar way as described for $\mathrm{K}$ ? New insights in such processes could provide important information which can be incorporated in sophisticated breeding programs for Mg-efficient crops.

\section{Methods of determining the plant available $\mathrm{Mg}$ in soils}

In view of the various functions of $\mathrm{Mg}$ in plants, the chemistry and mobility of $\mathrm{Mg}$ in soils and the mechanisms plants evolved to acquire $\mathrm{Mg}$ this section describes how plant and soil Mg levels can be determined. The challenge is to relate the data obtained 
from soil analysis to the phytoavailability and plant growth (Kopittke and Menzies 2007). Particularly questions related to determination of plant and soil thresholds for $\mathrm{Mg}$ deficiency and how these can be translated into appropriate agronomic strategies is discussed. A tool to diagnose the $\mathrm{Mg}$ status of a given production site is the evaluation of the $\mathrm{Mg}$ status of the soil and the crop at a pre-defined location and time (soil and plant analysis). For correct interpretation of the results obtained from such analyses calibration experiments are required for each crop and soil determining critical individual plant and soil Mg levels leading to deficiency. Also dose-response curves are needed in order to find plant and soil Mg levels leading to a yield threshold (concentration of a given nutrient in the plant dry matter leading to maximum yield). A good example for the combination of soil and plant analysis and calibration experiments is summarized in the review by Edmeades (2004). He reviewed the research conducted in New Zealand in the last 40 years on the development of diagnosis criteria to predict and strategies to manage soil, plant (pasture), and animal $\mathrm{Mg}$ nutrition. Soil, plant and animal $\mathrm{Mg}$ analysis were taken into account as well as further meta-data like rainfall. From this meta-analysis he concluded that on the one hand there are considerable amounts of $\mathrm{Mg}$ available in the topsoil but that these are slowly declining as a consequence of reduced $\mathrm{Mg}$ fertilizer input. Moreover, he could show that extreme deficiencies can be avoided in New Zealand by application of about $25 \mathrm{kgMg}$ ha $^{-1}$ year- ${ }^{1}$. A balanced state of soil $\mathrm{Mg}$ was achieved by applying $5-20 \mathrm{kgMg} \mathrm{ha}^{-1}$ year $-^{1}$. Interestingly, the author went further and could show that avoiding $\mathrm{Mg}$ deficiency in pasture was not sufficient to reduce the risk of hypomagnesaemia development in ruminants. The required higher concentrations in the pasture could only be achieved by high soil $\mathrm{Mg}$ levels or, when the $\mathrm{Mg}$ levels were low, large inputs of $\mathrm{Mg}$ to the soil ( $>100 \mathrm{kgMg} \mathrm{ha}^{-1}$ year $^{-1}$ ).

\section{Soil analysis}

Relating the Mg content of a soil to plant growth and phytoavailability is a challenging topic (see previous section). Several different soil analysis methods are used to predict phytoavailability of nutrients making a direct comparison of the results sometimes rather difficult. However, some of the most important questions, which need to be answered and standardized, are: What are the decisive soil $\mathrm{Mg}$ fractions (water-soluble, exchangeable, fixed) for plant $\mathrm{Mg}$ nutrition? How can they be determined (which extraction methods)? What is an appropriate sampling type to cover the plants' ability to take up $\mathrm{Mg}$ from the soil (topsoil and subsoil)?

Ortas et al. (1999) state, that there is often a poor relationship between the plant growth response and extractable nutrients in the soil. What is the reason for this phenomenon? One reason is that such a soil analysis just gives a picture of the current situation at a given site, which is difficult to extrapolate to the future. It is not capable of perfectly simulating the above mentioned plant characteristics on $\mathrm{Mg}$ uptake (see section 'Mechanisms of Mg uptake by crops'). Also, other agronomic and environmental (drought stress etc.) factors are not included. Consequently, and this does not only apply for $\mathrm{Mg}$, soil analysis only gives information on the potential of a soil to provide the respective nutrient. An idea of the complexity of soil analysis is given by a recent study of Staugaitis and Rutkauskienè (2010) who compared six different magnesium extraction and determination methods. From the results shown in Table 2 it can be clearly seen that the extraction procedure strongly impacts the outcome. Nevertheless, all mild extraction procedures including $\mathrm{CaCl}_{2}, \mathrm{KCl}, \mathrm{NH}_{4} \mathrm{OAc}$ and the Mehlich 3 method showed quite high correlations over all three sampling depths investigated indicating similar extraction characteristics for $\mathrm{Mg}$ from soils. In contrast particularly the strong A-L method and the $\mathrm{H}_{2} \mathrm{O}$ extraction method showed only very little correlation with almost all other extraction procedures over all sampling depths. These results show the importance of chosing an appropriate extraction method for correct evaluation of the $\mathrm{Mg}$ availability to a crop.

Concerning the evaluation of the contribution of different soil $\mathrm{Mg}$ pools to plant $\mathrm{Mg}$ nutrition early results indicate that the water-soluble and exchangeable soil Mg fractions do not always reflect the crops' capacity to mine the soil. In fact, no close relationship between the water-soluble and exchangeable soil $\mathrm{Mg}$ status in the topsoil and the $\mathrm{Mg}$ concentration in the plants was observed (Fig. 2, Grimme 1978, exchangeable fraction extracted with $\mathrm{CaCl}_{2}$ ). From Fig. 2 it can also be concluded that depending on the crop type the subsoil considerably contributes to the $\mathrm{Mg}$ nutrition of crops. In another early study Papenfuß and Schlichting (1979) employed two different extraction methods simulating the extraction of the water-soluble and 
Table 2 Correlation coefficients of different $\mathrm{Mg}$ extraction procedures. Soil samples from 21 different Lithuana sites (differing in topology, $\mathrm{pH}$ and texture) were sampled over three layers $(0-30 \mathrm{~cm}, 30-60 \mathrm{~cm}, 60-90 \mathrm{~cm})$. Six different extraction procedures were compared. Data modified after Staugaitis and Rutkauskienè (2010)

\begin{tabular}{|c|c|c|c|c|c|}
\hline Methods $^{\mathrm{a}}$ & A-L & $\mathrm{CaCl}_{2}$ & $\mathrm{KCl}$ & $\mathrm{NH}_{4} \mathrm{OAc}$ & $\mathrm{Me}-3$ \\
\hline \multicolumn{6}{|c|}{$0-30 \mathrm{~cm}$ layer } \\
\hline $\mathrm{CaCl}_{2}$ & 0.204 & & & & \\
\hline $\mathrm{KCl}$ & 0.217 & 0.982 & & & \\
\hline $\mathrm{NH}_{4} \mathrm{OAc}$ & 0.250 & 0.974 & 0.996 & & \\
\hline $\mathrm{Me}-3$ & 0.302 & 0.970 & 0.991 & 0.995 & \\
\hline $\mathrm{H}_{2} \mathrm{O}$ & 0.248 & 0.533 & 0.544 & 0.570 & 0.551 \\
\hline \multicolumn{6}{|c|}{$30-60 \mathrm{~cm}$ layer } \\
\hline $\mathrm{CaCl}_{2}$ & 0.418 & & & & \\
\hline $\mathrm{KCl}$ & 0.394 & 0.972 & & & \\
\hline $\mathrm{NH}_{4} \mathrm{OAc}$ & 0.456 & 0.981 & 0.984 & & \\
\hline $\mathrm{Me}-3$ & 0.520 & 0.967 & 0.975 & 0.993 & \\
\hline $\mathrm{H}_{2} \mathrm{O}$ & 0.026 & 0.298 & 0.270 & 0.263 & 0.247 \\
\hline \multicolumn{6}{|c|}{$60-90 \mathrm{~cm}$ layer } \\
\hline $\mathrm{CaCl}_{2}$ & 0.546 & & & & \\
\hline $\mathrm{KCl}$ & 0.509 & 0.956 & & & \\
\hline $\mathrm{NH}_{4} \mathrm{OAc}$ & 0.595 & 0.969 & 0.985 & & \\
\hline $\mathrm{Me}-3$ & 0.626 & 0.956 & 0.979 & 0.997 & \\
\hline $\mathrm{H}_{2} \mathrm{O}$ & 0.087 & 0.395 & 0.327 & 0.331 & 0.284 \\
\hline
\end{tabular}

${ }^{\mathrm{a}}$ Methods used were:

A-L - $1 \mathrm{M}$ lactic acid, $3 \mathrm{M}$ acetic acid, $1 \mathrm{M}$ ammonium acetate, $\mathrm{pH}$ 3.7, soil:solvent ratio 1:20, extraction duration $4 \mathrm{~h}$

Me-3 - 0.2 M acetic acid, $0.015 \mathrm{M}$ ammonium fluoride, $0.013 \mathrm{M}$ nitric acid, $0.25 \mathrm{M}$ ammonium nitrate, $0.001 \mathrm{M}$ ethylenediaminetetraacetic acid (EDTA), $\mathrm{pH} 2.5$, soil:solvent ratio $1: 10$, extraction duration $5 \mathrm{~min}$.

$\mathrm{CaCl}_{2}-0.0125$ Calcium chloride, soil:solvent ration 1:20, extraction duration $1 \mathrm{~h}$

$\mathrm{KCl}-1 \mathrm{M}$ Potassium chloride, soil:solvent ratio 1:10, extraction duration $1 \mathrm{~h}$

$\mathrm{NH}_{4} \mathrm{OAc}-1 \mathrm{M}$ ammonium acetate, $\mathrm{pH}$ 7.0, soil:solvent ratio $1: 10$, extraction duration $1 \mathrm{~h}$

$\mathrm{H}_{2} \mathrm{O}$ - water, soil:solvent ratio 1:5, extraction duration $1 \mathrm{~h}$

exchangeable pool on the one hand $\left(\mathrm{CaCl}_{2}\right)$ and the fixed pool on the other hand $(\mathrm{HCl})$ and correlated these findings with $\mathrm{Mg}$ uptake by plants. From Fig. 3 representing the data published by Papenfuß and Schlichting (1979) it can be concluded, that among the water-soluble and exchangeable soil $\mathrm{Mg}$ pool also the fixed $\mathrm{Mg}$ pool of the soil can substantially contribute to plant $\mathrm{Mg}$ nutrition. However, in literature inconsistent results are reported on the contribution of the fixed soil $\mathrm{Mg}$ pool to plant $\mathrm{Mg}$ nutrition: in some intensive cropping systems a negligible contribution of the fixed soil $\mathrm{Mg}$ pools to crop nutrition has been found (Salmon and Arnold 1963; Christenson and Doll 1973; Kidson et al. 1975), whereas other authors report more variation in the magnitude of $\mathrm{Mg}$ delivery depending on the soil type (Schroeder et al. 1962; Rice and Kamprath 1968; Lombin and Fayemi 1975). However, there are only very few reports available on the potential of the fixed $\mathrm{Mg}$ fraction to contribute to plant nutrition.

Another potential source of $\mathrm{Mg}$ in soils is the soil organic matter. There is only rare information available in literature on the contribution of soil organic matter to the $\mathrm{Mg}$ level of soils and its contribution to plant mineral nutrition (Mayland and Wilkinson 1989). With respect to plant $\mathrm{Mg}$ nutrition soil organic matter is widely treated as provider of variable charge in soils increasing the CEC of soils. However, the organically bound $\mathrm{Mg}$ can be an important source of Mg in some specific soils (Mayland and Wilkinson 1989). Nevertheless, the lack of knowledge on the contribution of $\mathrm{Mg}$ mineralization to $\mathrm{Mg}$ nutrition of crops again points to the importance of future research efforts to be put on this topic.

Plant analysis

Development of appropriate agronomic strategies to prevent $\mathrm{Mg}$ deficiency requires careful diagnosis of $\mathrm{Mg}$ deficiency in plants. Indeed, already the diagnosis of $\mathrm{Mg}$ deficiency in crops represents a challenge on its

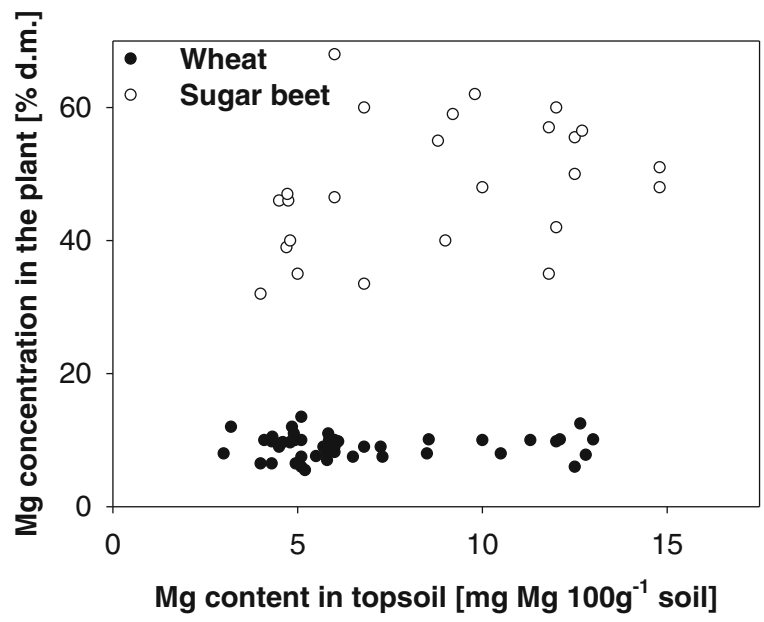

Fig. 2 Relationship between $\mathrm{Mg}$ content in the topsoil and $\mathrm{Mg}$ concentration in wheat and sugar beet. (Graph redrawn after Grimme 1978) 


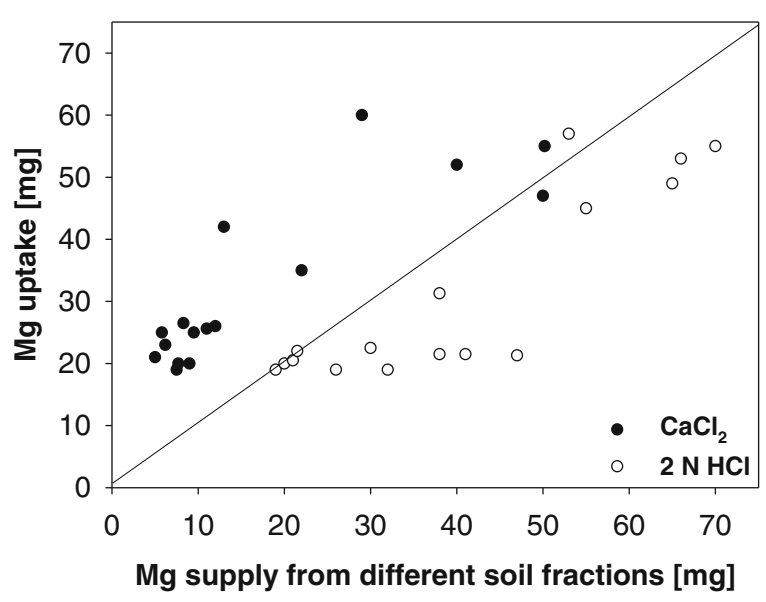

Fig. 3 Relationship between $\mathrm{Mg}$ uptake by plants and $\mathrm{Mg}$ supply from different soil fractions. (Graph redrawn after Papenfuß and Schlichting 1979)

own. For correct identification of $\mathrm{Mg}$ deficiency the relationship between $\mathrm{Mg}$ concentration in the plant matter and occurrence of deficiency symptoms needs to be determined. The following questions have to be addressed and standardized by the use of calibration experiments: What is the deficiency threshold for a crop ( $\mathrm{Mg}$ concentration in the plant dry matter at which deficiency symptoms occur)? What on the other hand is the yield threshold for a given crop (concentration of $\mathrm{Mg}$ in the plant dry matter to obtain (economically) maximum yield)? Which plant organ needs to be analyzed (old leaves, young leaves)? Are there specific growth stages which need to be particularly addressed? To answer these questions basic knowledge on the functions of $\mathrm{Mg}$ in plants is necessary in order to correctly sample the plants.

Magnesium deficiency symptoms are typically associated with interveinal chlorosis particularly on older leaves as $\mathrm{Mg}$ is readily phloem-mobile and, therefore, retranslocated (White and Broadley 2008). Hence, deficiency symptoms of Mg should appear on older leaves, making these leaves the most important ones for determining deficiency thresholds. A standardized sampling time is of particular importance due to the high variation in the $\mathrm{Mg}$ concentrations during the growth period (Čmelik 2000; Dow and Roberts 1981). However, chlorosis is a quite late expression symptom of $\mathrm{Mg}$ deficiency. It can be assumed that (particularly in phases of high crop growth rates) latent $\mathrm{Mg}$ deficiency frequently occurs. Latent deficiency, however, is already yield relevant. As mentioned in the introduction part a typical early response of plants to $\mathrm{Mg}$ deficiency is reduced root growth (Cakmak et al. 1994a, b), even though this effect obviously does not appear in all crops (for example sugar beet, see Hermans et al. 2004; Hermans and Verbruggen 2005). Future work should clarify the reason for the discrepancies in the sensitivity of root growth to $\mathrm{Mg}$ deficiency observed in these studies. However, it can be stated that root growth might be a more reliable indicator for Mg deficiency than chlorosis. Reduced root growth is most likely a consequence of impaired phloem transport of carbohydrates (and other metabolites) from the shoot to the root. Nevertheless, a cost effective and reliable diagnosis of root growth under field conditions is almost impossible to realize and methods are not available. Another more promising and practicable link for recognizing $\mathrm{Mg}$ deficiency at early stages could be the determination of the sugar concentration in leaves upon $\mathrm{Mg}$ deficiency as this was shown to be an early deficiency response and thought to be the 'precursor' of reduced root growth (Cakmak et al. 1994a, b; Hermans et al. 2004; Hermans and Verbruggen 2005). It would be interesting to correlate the $\mathrm{Mg}$ content with sugar accumulation and root growth in order to develop a reliable field test for latent $\mathrm{Mg}$ deficiency. Also it would be interesting whether such a method would be more precise in displaying latent $\mathrm{Mg}$ deficiency than measuring the $\mathrm{Mg}$ concentration in the plant dry matter.

\section{Strategies to bring Mg availability and demand in accordance}

In this section environmental, soil- and plant-related factors leading to $\mathrm{Mg}$ deficiency are highlighted and strategies to cope with these challenges, e.g. those based on soil and plant analysis, are presented. Where appropriate, also the question is addressed whether new plant physiological insights need to be applied to fertilization recommendations.

Conditions of absolute deficiency and imbalanced nutrient availability

There are at least two main sometimes interrelated reasons for absolute Mg deficiency: (i) The $\mathrm{Mg}$ content of the source material forming the soil is low (see section 'Origin of magnesium in soils'). (ii) Long-term $\mathrm{Mg}$ depletion of soils. The depletion is a consequence of $\mathrm{Mg}$ leaching or soil mining due to imbalanced crop 
offtake / resupply (fertilization) ratios (see section 'Consequences of the mobility of Mg in soils'). In such soils it is indispensable to supply the soils with $\mathrm{Mg}$ in order to maintain or even improve soil fertility. However, of course this not only applies to $\mathrm{Mg}$ but also to other base cations. It is obvious that the fertilization practice modulates the soil fertility, e.g. through direct modification of the plant availability of the nutrients in the soil. Thereby, fertilization not only changes the availability of the nutrients supplied with fertilization but also affects the availability of nutrients present in the soil. With respect to $\mathrm{Mg}$ nutrition $\mathrm{K}$ and $\mathrm{Ca}$ modulate plant $\mathrm{Mg}$ availability due to two reasons: (i) increased Mg exchange from soil exchange sites and, therefore, increased $\mathrm{Mg}$ concentrations in the soil solution with increased risk of $\mathrm{Mg}$ losses by leaching and (ii) shifts in the quantitative and qualitative cation composition in the soil leading to cation competition at the plant root for uptake (see section 'Mechanisms of $\mathrm{Mg}$ uptake by crops'). Table 3 shows how $\mathrm{K}$ fertilization increases the concentration not only of $\mathrm{K}$ but also of $\mathrm{Mg}$ in the soil solution (Seggewiss and Jungk 1988). These interrelationships particularly between the base cations highlight the importance of a balanced fertilization.

Cation competition due to imbalanced nutrient availability to plants is due to imbalanced nutrient supply either through agronomic practices (liming (see above), fertilization strategy) or delivery from the soil. The phenomenon of cation competition was already described previously (see section 'Mechanisms of $\mathrm{Mg}$ uptake by crops'). Cation competition is a complex problem and points to the need of (in certain limits) balanced nutrient supply to crops for efficient crop production. This is particularly important for soils inherently not capable of providing balanced nutrient supply. Soils rich in chlorites are principally capable of fixing $\mathrm{Mg}$ (see section 'Origin of magnesium in soils'). In such soils the risk of $\mathrm{Mg}$ deficiency is not only due to the absolute deficiency but also due to enhanced risk of induced $\mathrm{Mg}$ deficiency resulting from cation antagonism as a consequence of increased availability of other cations like $\mathrm{K}$ and $\mathrm{Ca}$. In such soils improvement and maintenance of a balanced nutrient supply to crops is extraordinary important. The fixing sites need to be filled up with $\mathrm{Mg}$ through a fertilization strategy which provides $\mathrm{Mg}$ in amounts much higher than extracted with the crop. Few reports are available on $\mathrm{Mg}$ fixation in soils, e.g. in response to fertilization practice. In their report on the effect of liming on yield parameters
Table 3 Effect of an increased $\mathrm{K}$ fertilization on the concentration of exchangeable $\mathrm{K}$ in the soil and the concentrations of $\mathrm{K}$ and $\mathrm{Mg}$ in soil solution (adapted from Seggewiss and Jungk 1988)

\begin{tabular}{lccc} 
K fertilization & Exchangeable $\mathrm{K}$ & $\begin{array}{l}\text { Concentration } \\
\text { in soil solution }\end{array}$ \\
\cline { 3 - 4 }$\left(\mu \mathrm{molK} 100 \mathrm{~g}^{-1}\right.$ soil $)$ & $\left.(\mu \mathrm{molKl})^{-1}\right)$ & $\left(\mu \mathrm{molMgl}^{-1}\right)$ \\
\hline 0 & 153 & 58 & 1180 \\
200 & 220 & 108 & 1620 \\
400 & 280 & 142 & 2000 \\
800 & 390 & 278 & 2630 \\
1600 & 760 & 1600 & 3400 \\
\hline
\end{tabular}

Sumner et al. (1978) suggested that often observed negative yield responses after liming could be a consequence of $\mathrm{Mg}$ fixation. The data set the authors provided was not sufficient to completely clarify the mechanism of $\mathrm{Mg}$ fixation after liming but provided some ideas: (i) formation of $\mathrm{Mg}$-silicates, (ii) immobilization of $\mathrm{Mg}$ in the interlayer of aluminous chlorites, (iii) formation of insoluble mixed hydroxides with active $\mathrm{Al}$ under alkaline conditions, (iv) absorption of Mg on Al-hydroxides. Mokwunye and Melsted (1973) evaluated the extent of immobilization of $\mathrm{Mg}$ added to soils of temperate and tropic origin and concluded that it was not possible to improve the 'long-term Mg-supplying power of soils' which indicates 'the importance of repeated application of Mg fertilizers, especially in highly weathered soils' (Mokwunye and Melsted 1973).

Magnesium deficiencies related to adverse growth conditions

\section{Light, drought, and heat stress}

High light stress, often associated with drought and heat stress, represents a major challenge in crop production (Mittler 2006). According to the forecasts the frequency of extreme weather conditions will increase due to processes involved in climatic change (Easterling et al. 2000). The roles of Mg in plant metabolism particularly under stress conditions are well known (Cakmak and Kirkby 2008). Magnesium is involved in carbohydrate formation and translocation. However, under Mg deficient conditions these processes of the primary metabolism are severely disturbed. Cakmak and Kirkby (2008) concluded from experiments investigating the effect of light treatments on Mg-deficient leaves that the $\mathrm{Mg}$ 
requirement is increased under high-light conditions. The higher requirement of $\mathrm{Mg}$ under high light might be reduced to the fact that under suboptimal Mg supply and high light processes are induced which finally lead to accumulation of reactive oxygen species (ROS) and thus plant damage. Much higher activities of antioxidative enzymes such as superoxide dismutase and ascorbate peroxidase in $\mathrm{Mg}$-deficient leaves compared to $\mathrm{Mg}$-adequate leaves indicate that $\mathrm{Mg}$ deficiency stress, indeed, induce generation of reactive oxygen species as a consequence of impairments in photosynthetic electron transport and utilization of photoassimilates (Cakmak and Marschner 1992). Hence, the described higher $\mathrm{Mg}$ demand is simply due to the essential roles of $\mathrm{Mg}$ in primary metabolism, which cannot be optimally fulfilled under $\mathrm{Mg}$ deficient conditions. Consequently, in plants well supplied with $\mathrm{Mg}$ differences in light stress susceptibility are not observed, so that under optimal $\mathrm{Mg}$ supply no further demand for $\mathrm{Mg}$ can be suggested. However, as initially mentioned high light, drought, and heat stress typically occur at the same time. Therefore, in agricultural practice there is an increased risk of temporarily occurring $\mathrm{Mg}$ deficiency due to reduced delivery of $\mathrm{Mg}$ by mass flow. With respect to the crop $\mathrm{Mg}$ demand plant biomass production typically follows a sigmoidal curve with low biomass accumulation after emergence, followed by an exponential vegetative growth and finally a plateau during generative growth and yield formation. Particularly in periods where an increased risk of low Mg availability (e.g. drought) is synchronized with high crop growth rates and therefore high $\mathrm{Mg}$ demand, there is an increased risk that the soil $\mathrm{Mg}$ pool and soil applicated sparingly water-soluble $\mathrm{Mg}$ fertilizers/limes cannot meet the actual crop demand for $\mathrm{Mg}$. This is particularly true for important crops exhibiting extraordinary high growth rates and, therefore, nutrient demands (C4 plants like maize and sugarcane). Here leaf and/or soil application of readily available $\mathrm{Mg}$ sources can be advantageous (Römheld and Kirkby 2007). This view was underlined by Härdter et al. (2004), who investigated the effect of different $\mathrm{Mg}$ fertilizer sources on $\mathrm{Mg}$ availability in soils. The authors recommended that for maximization of crop uptake while minimizing $\mathrm{Mg}$ losses $\mathrm{Mg}$ sources exhibiting a gradual but strong release matching the plants requirements should be applied. The source of $\mathrm{Mg}$ applied to meet actual high demands should among water-solubility also consider the accompanying ion, which is introduced into the system and, particularly for leaf fertilization, the capacity of a specific $\mathrm{Mg}$ salt to induce leaf burning symptoms. Figure 4 shows the solubility of some different $\mathrm{Mg}$ salts. Römheld and Kirkby (2007) state that foliar Mg fertilization would be effective particularly in combination with $\mathrm{N}$ quality fertilization during reproductive stages as the assimilate transport into harvest organs (tubers, grains, fruits etc.) is enhanced and thereby the competition between the root as second strong sink is reduced. However, in terms of yield security maintained root growth further offers the advantage of continuous water and nutrient supply under drought stress.

\section{Acid soils—low pH and metal toxicities}

Magnesium deficiency is problem inherent in acid soils due to the high saturation of the soil $\mathrm{CEC}$ with $\mathrm{H}^{+}$ions and consequent $\mathrm{Mg}$ leaching for long time periods and impaired $\mathrm{Mg}$ uptake (see sections above). Indeed, already 60 to 70 years ago first studies reported that a low $\mathrm{pH}$ of soils exhibit higher leaching rates for $\mathrm{Mg}$ (Schachtschabel 1954, and literature cited therein). Von Uexkull and Mutert (1995) estimated that about $30 \%$ of the total ice-free land area in the world is acidic (defined as $\mathrm{pH}<5.5$ in the top soil layers) representing about 4 billion ha. In view of arable land expansion Haug (1983) even estimated that about $70 \%$ of the potentially arable land is acidic. Soil acidity is not only a soil immanent problem but is additionally further enhanced by agricultural fertilization practice. Indeed,

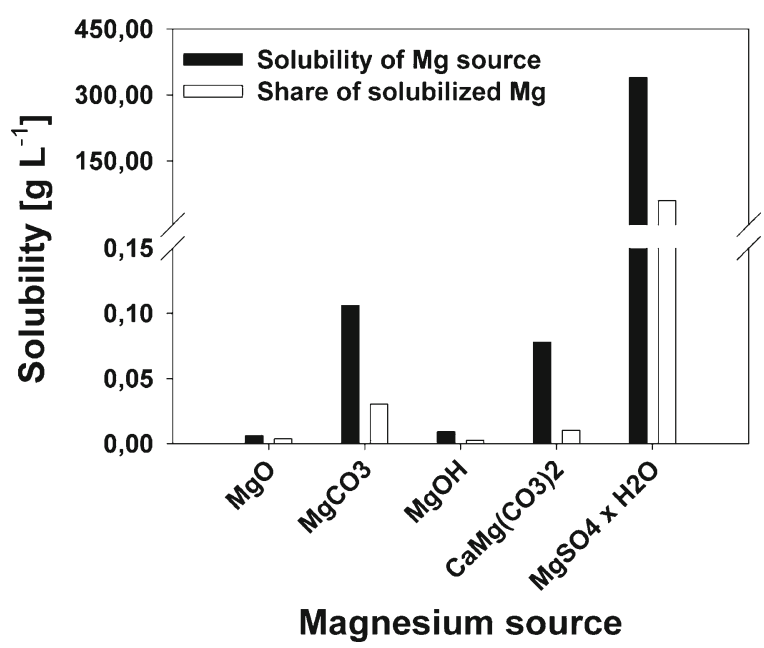

Fig. 4 Solubility of different $\mathrm{Mg}$ fertilizer salts in water at $20^{\circ} \mathrm{C}$. Black bars show the solubility of the $\mathrm{Mg}$ salts and white bars show the corresponding amounts of solubilized $\mathrm{Mg}$ 
Guo et al. (2010) could measure a significant effect of excessive $\mathrm{N}$ and base cation fertilization on soil acidification in China by comparing soil $\mathrm{pH}$ and fertilization practice of different Chinese soils in the 1980s and 2000s. Among the quantitative cation composition of soils the soil acidity also impacts $\mathrm{Mg}$ uptake by plants as low $\mathrm{pH}$ impairs the uptake of base cations. The $\mathrm{pH}$ dependency of the plant availability of three base cations is schematically shown in Fig. 5 for a $\mathrm{pH}$ range realistic for arable land. The decrease of plant availability particularly of the two base cations $\mathrm{Ca}$ and $\mathrm{Mg}$ at acidic $\mathrm{pH}$ $(<\mathrm{pH} 6)$ is a consequence of the increasing inability to build up and maintain a sufficient $\mathrm{pH}$ and hence electrochemical gradient across the plasma membrane of root cells (Schubert et al. 1990). Among an impaired availability and uptake of base cations like $\mathrm{Ca}$ and $\mathrm{K}$ soil acidity leads to several additional adverse effects. At soil $\mathrm{pH}<4-4.5$ the root growth is directly inhibited by $\mathrm{H}^{+}$ toxicity with severe consequences for crop production (Islam et al. 1980; Koyama et al. 1995; Rangel et al. 2005). However, acid soils bear also the risk of element toxicities, particularly $\mathrm{Mn}$ and $\mathrm{Al}$. Manganese is an essential plant micronutrient, whereas $\mathrm{Al}$ is not required by plants, even though some plant species accumulate Al in their tissue (Klug and Horst 2010; Ma et al. 2001 [Fagopyrum esculentum], Matsumoto et al. 1976 [Camellia sinensis], Ma et al. 1997 [Hydrangea macrophylla]) This section is included due the substantial progress made in the last years in clarifying the role of $\mathrm{Mg}$ in metal toxicity stress alleviation.

Starting with Mn there is a considerable inter- and intraspecific (between plant species and between cultivars within a plant species) variability in tolerance to excess Mn (Foy et al. 1978). However, several studies report a beneficial effect of $\mathrm{Mg}$ supply on Mn tolerance of crops (Le Bot et al. 1990; Goss and Carvalho 1992). For wheat Goss and Carvalho (1992) reported that $\mathrm{Mg}$ "increased the tolerance of plants to high concentrations of manganese in shoot tissue and also increased the ability of the plant to discriminate against manganese ions in translocation of nutrients from roots to shoots." Le Bot et al. (1990) found that increasing the $\mathrm{Mg} / \mathrm{Mn}$ ratio in the plant tissue alleviates $\mathrm{Mn}$ toxicity in tomato and wheat. It is noteworthy here that obviously $\mathrm{Mg}$ reduced Mn toxicity not only by reducing Mn uptake (cation antagonism) but also by increasing the plant tissue tolerance. Malcová et al. (2002) found that the toxic effect of excess Mn can be alleviated by adding $\mathrm{Mg}$. This was not only true for in-vitro experiments but also for the symbiotic association between the arbuscular mycorrhizal fungi and maize as host plant. To our knowledge the mechanisms underlying the increasing effect of $\mathrm{Mg}$ on $\mathrm{Mn}$ tissue tolerance are not yet understood.

The alleviative effect of $\mathrm{Mg}$ on $\mathrm{Al}$ toxicity is recognized for a long time in several plant species (Edmeades et al. 1991 [Triticum aestivum], Keltjens and Tan 1993 [Helinathus annuus, Glycine max, Vigna unguiculata, Arachis hypogaea, Cucumis sativus, Lycopersicum esculentum, Brassica capitata ssp., Oryza sativa, Zea mays, Secale cereale, Sorghum bicolor, Triticum aestivum, Hordeum vulgare, Avena sativa]; Tan and Keltjens 1995 [Sorghum bicolor]; Silva et al. 2001 [Glycine max]; Hecht-Buchholz and Schuster 1987 [Hordeum vulgare]), but up to date the exact mechanisms underlying this phenomenon are not yet fully understood as well. Bose et al. (2011) summarized the potential positive effects of $\mathrm{Mg}$ in the plants' physiology to increase the resistance/tolerance of crop plants to toxic $\mathrm{Al}^{3+}$. It appears that there is not a single reason responsible for the alleviative effect of $\mathrm{Mg}$ on $\mathrm{Al}$ toxicity expression but a coordinated interplay between several factors including better carbohydrate partitioning and organic acid synthesis and secretion (see also Ma et al. 2001),
Fig. 5 Scheme of the plant availability of mineral nutrients in dependence of the soil $\mathrm{pH}$

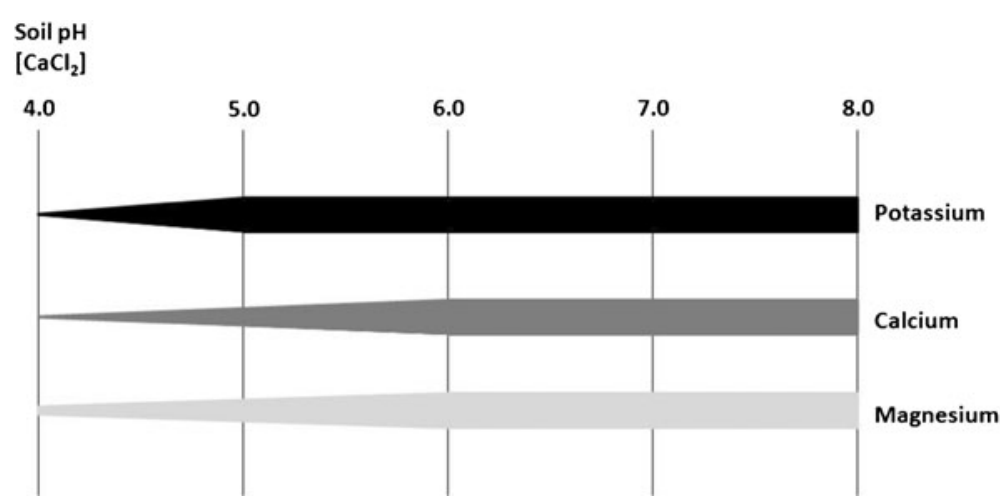


enhanced phosphatase activity, better $\mathrm{H}^{+}$-ATPase activity and cytoplasmic $\mathrm{pH}$ regulation, protection from $\mathrm{Al}-$ induced increase in cytosolic $\mathrm{Ca}$ concentrations and reactive oxygen species. Interestingly, Deng et al. (2006) provided evidence that overexpression of a magnesium transport gene from Arabidopsis thaliana (AtMGT1) conferred tolerance to $\mathrm{Al}$ in Nicotiana benthamiana indicating that increased internal $\mathrm{Mg}$ concentrations are necessary for this effect. The association of increased $\mathrm{Mg}$ uptake and $\mathrm{Al}$ tolerance was also very recently verified for rice, an extraordinary $\mathrm{Al}$ tolerant plant species (Chen et al. 2012; Chen and Ma 2012). The expression of a rice $\mathrm{Mg}$ transporter (OsMGT1) was regulated by $\mathrm{Al}$ availability, and knockout of this gene enhanced $\mathrm{Al}$ sensitivity of rice. The upregulation of a $\mathrm{Mg}$ transporter under $\mathrm{Al}$ stress was accompanied by increased $\mathrm{Mg}$ uptake by the rice plant through enhanced $\mathrm{V}_{\text {max }}$ of the protein. Whether the increased tolerance of rice due to increased $\mathrm{Mg}$ uptake is a consequence of a specific Mg function or of the more efficient metabolic regulation of $\mathrm{Mg}$-associated pathways in the plant as described by Bose et al. (2011), remains to be elucidated. Future work should clarify the exact underlying mechanisms as well. Moreover, it would be interesting to investigate whether $\mathrm{Al}$ stress induces a higher $\mathrm{Mg}$ demand for optimal plant growth also in the field, and when yes, to which extent (Is an adaption of the recommendation for $\mathrm{Mg}$ supply necessary?).

Even though $\mathrm{Mg}$ is obviously capable of alleviating the adverse effects occurring on acid soils, on the long-term the most important agronomic tool to cope with soil acidity is liming. Among reducing soil acidity and associated adverse growth conditions liming is supposed to also improve and sustain soil structure and fertility (Haynes and Naidu 1998). Commonly used lime types are dolomitic lime $\left(\mathrm{CaMg}\left(\mathrm{CO}_{3}\right)_{2}\right)$, calcitic lime $\left(\mathrm{CaCO}_{3}\right)$ and dolomitic lime $\left(\mathrm{MgCO}_{3}\right)$ (Fageria 2009). However, depending on the lime type considerable amounts of $\mathrm{Mg}$ and $\mathrm{Ca}$ reach the soil which may then interfere with the uptake of other cations through antagonistic effects (see also section 'Mechanisms of Mg uptake by crops'). Stevens et al. (2005) could not find negative impacts of short- and long-term liming with calcite or dolomite on cotton growth in field experiments with well drained soils, whereas Sumner et al. (1978) reported from their comprehensive data evaluation of soils from North America and Africa consistent reductions in $\mathrm{Mg}$ uptake by plants when soils were limed to neutrality which could be reduced to pure Ca containing lime application (see also previous section dealing with $\mathrm{Mg}$ fixation). These two contrasting studies may indicate the complexity of this topic.

Use of appropriate nitrogen form

For wheat it has been shown that the $\mathrm{N}$ form supplied impacts not only the $\mathrm{Mg}$ uptake but also the translocation from the root to the shoot. Increasing the $\mathrm{NO}_{3}{ }^{-}$ supply increased the uptake of $\mathrm{Mg}$ but decreased the translocation (Huang and Grunes 1992). Particularly under low $\mathrm{Mg}$ conditions there was a higher risk of $\mathrm{Mg}$ deficiency symptom development. In contrast, in tomato it was shown that increasing the $\mathrm{NO}_{3}{ }^{-}$nutrition increased the cation concentration in the shoots (Kirkby and Knight 1977). It was suggested that cations act as counter-ions for $\mathrm{NO}_{3}{ }^{-}$in root to shoot translocation (for more information on the effect of mineral nutrition on partitioning of minerals and metabolites see Marschner et al. 1996). These contrasting results show that future research is necessary to understand these and additional differences in nutritional physiology in order to improve crop-specific fertilization recommendations.

\section{Use of Mg efficient cultivars}

A long standing research area in crop sciences and particularly in the field of plant nutrition is the investigation of nutrient use efficiency (NUE). Several measures of NUE were developed over the last decades (see for example Gourley et al. 1994). However, NUE is typically regarded as a crops capacity to produce high yield under limited nutrient supply. Hence, choice of $\mathrm{Mg}$ efficient crops/crop cultivars could be another important agronomic factor to deal with low plant $\mathrm{Mg}$ availability. This appears to be particularly true for low input agricultural systems. However, so far breeding programs more or less neglected the plant nutrient $\mathrm{Mg}$, so that there is no or only rarely respective germplasm available (Clark 1983; Beets et al. 2004 [Pinus radiata]). Future research programs should, therefore, also include breeding programs producing $\mathrm{Mg}$ efficient crops. Alternatively growers can draw back on existing crops/cultivars with low demand for Mg. However, this mostly excludes most important crops typically grown in subsistence farming like maize and pulses, further narrowing food availability and diversity. 
Soil organic matter and organic fertilization as sources of $\mathrm{Mg}$ and modulators of $\mathrm{Mg}$ availability

As mentioned above the contribution of soil organic matter (SOM) on plant $\mathrm{Mg}$ nutrition is mainly reduced to provision of charge to the $\mathrm{CEC}$, whereas the $\mathrm{Mg}$ content of SOM is thought to be rather limited (Mayland and Wilkinson 1989). Unfortunately there is only very little information available on the contribution of SOM to plant $\mathrm{Mg}$ nutrition. With respect to organic fertilization the situation is different. Among modification of the CEC of soils organic fertilization can also have an effect on crop nutrition with respect to $\mathrm{Mg}$ supply. As the mean $\mathrm{Mg}$ concentrations of different organic material sources used for organic fertilization vary considerably the applied amounts of $\mathrm{Mg}$ and also other relevant cations need to be taken into account for sustainable agricultural practice. Eghball et al. (2002) stated that more than $55 \%$ of the organically applied $\mathrm{Mg}$ is plant available. Allison et al. (1997) reported that in sugar beet grown on soils where straw was incorporated the uptake of $\mathrm{Mg}$ but also of phosphorus (P) and $\mathrm{Ca}$ was not significantly affected, whereas the $\mathrm{K}$ uptake was increased by about $40 \mathrm{kgha}^{-1}$. However, it has been shown, that organic fertilization increases the $\mathrm{Mg}$ content of soils and prevents higher amounts of $\mathrm{Mg}$ to be leached into soil layers not or sparingly reached by plant roots (Piechota et al. 2000; Grzebisz 2011).

\section{Conclusion}

The mobility of $\mathrm{Mg}$ in soils and plants is principally understood and transferred to soil and plant analysis methods aiming at developing appropriate recommendations for crop nutrition. However, inherent to soil analysis methods is that they can only predict the potential of a soil to deliver Mg to the plant roots. Accordingly plant analysis methods reflect only the current nutritional status of plants but are not capable of predicting the $\mathrm{Mg}$ availability. Combination of soil and plant analysis and the use of calibration experiments on production sites admittedly allow developing recommendations for $\mathrm{Mg}$ nutrition of crops to a certain degree. However, the often observed contrasting results on the effect of $\mathrm{Mg}$ fertilization on crop yield and other parameters show that other, additional factors are involved in crop $\mathrm{Mg}$ nutrition, which are not covered by the current analysis methods.
Indeed it is not new, that the actual Mg availability over a growing season heavily depends on (i) various environmental factors (rainfall and timing etc.), (ii) site-specific conditions (soil type, availability of other nutrients etc.), and (iii) the crop species making a precise prediction almost impossible. Environmental factors can hardly be influenced and completely forecasted, whereas sitespecific soil conditions can be determined by soil and to a certain degree by plant analysis. Consequently, an improvement of the development of recommendations on $\mathrm{Mg}$ nutrition is most promising when the crop species is regarded in more detail. It is, therefore, concluded that the newest findings on the physiology of $\mathrm{Mg}$ uptake by plants (e.g. antagonistic effects as affected by transport systems) and the role of $\mathrm{Mg}$ in stress physiology (drought, heat, high radiation, low $\mathrm{pH}$, metal toxicity) should be increasingly recognized and incorporated into site-specific recommendations.

Acknowledgments The authors would like to thank the reviewers for their helpful suggestions.

Open Access This article is distributed under the terms of the Creative Commons Attribution License which permits any use, distribution, and reproduction in any medium, provided the original author(s) and the source are credited.

\section{References}

Allison MF, Chapman JL, Garat CE, Todd AD (1997) The potassium, sodium, magnesium, calcium and phosphate nutrition of sugarbeet (Beta vulgaris) grown on soils containing incorporated straw. J Sci Food Agric 74:216-220

Barber SA (1995) Soil nutrient availability: a mechanistic approach. Wiley, UK

Barber SA, Walker JM, Vasey EH (1963) Mechanisms for the movement of plant nutrients from the soil and fertilizer to the plant root. J Agric Food Chem 11:204-207

Beets PN, Oliver GR, Kimberly MO, Pearce SH, Rodgers B (2004) Genetic and soil factors associated with variation in visual magnesium deficiency symptoms in Pinus radiata. For Ecol Manag 189:263-279

Bergmann W (1992) Nutritional disorders of plants-development, visual and analytical diagnosis. Gustav Fischer Verlag, Germany

Bose J, Babourina O, Rengel Z (2011) Role of magnesium in alleviation of aluminium toxicity in plants. J Exp Bot 62:2251-2264

Boysen P (1977) Nährstoffauswaschung aus gedüngten und ungedüngten Böden in Abhängigkeit von Standorteigenschaften und Nutzung der Moränen- und Sandergebiete Schleswig-Holsteins. Dissertation, ChistianAlbrechts-Universtität Kiel 
Britto DT, Kronzucker HJ (2008) Cellular mechanisms of potassium transport in plants. Physiol Plant 133:637-650

Cakmak I, Kirkby EA (2008) Role of magnesium in carbon partitioning and alleviating photooxidative damage. Physiol Plant 133:692-704

Cakmak I, Marschner H (1992) Magnesium deficiency and high light intensity enhance activities of superoxide dismutase, ascorbate peroxidase and glutathione reductase in bean leaves. Plant Physiol 98:1222-1227

Cakmak I, Yazici AM (2010) Magnesium: a forgotten element in crop production. Better Crops 94:23-25

Cakmak I, Hengeler C, Marschner H (1994a) Partitioning of shoot and root dry matter and carbohydrates in bean plants suffering from phosphorus, potassium and magnesium deficiency. J Exp Bot 45:1245-1250

Cakmak I, Hengeler C, Marschner H (1994b) Changes in phloem export of sucrose in leaves in response to phosphorus, potassium and magnesium deficiency in bean plants. J Exp Bot 45:1251-1257

Chen ZC, Ma JF (2012) Magnesium transporters and their role in Al tolerance in plants. Plant Soil. doi:10.1007/s11104012-1433-y

Chen ZC, Yamaji N, Motoyama R, Nagamura Y, Ma JF (2012) Upregulation of a magnesium transporter gene OsMGT1 is required for conferring aluminium tolerance in rice. Plant Physiol. doi:10.1104/pp.112.199778

Christenson DR, Doll EC (1973) Release of magnesium from soil clay and silt fractions during cropping. Soil Sci 116:59-63

Clark RB (1983) Plant genotype differences in the uptake, translocation, accumulation, and use of mineral elements required for plant growth. Plant Soil 72:175-196

Čmelik Z (2000) Seasonal changes in magnesium concentration of bearing plum shots. Agric Conspec Sci 65:161-167

Damm S, Hofmann B, Gransee A, Christen O (2011) Zur Wirkung von Kalium auf ausgewählte bodenphysikalische Eigenschaften und den Wurzeltiefgang landwirtschaftlicher Kulturpflanzen. Arch Agron Soil Sci. doi:10.1080/ 03650340.2011.596827

De Wit HA, Aldhuset TD, Mulder J (2010) Dissolved A1 reduces $\mathrm{Mg}$ uptake in Norway spruce forest: results from a long-term field manipulation experiment in Norway. Forest Ecol Manag 259:2072-2082

Deng W, Luo K, Li D, Zheng X, Wei X, Smith W, Thammina C, Lu L, Li Y, Pei Y (2006) Overexpression of an Arabidopsis magnesium transport gene, AtMGT1, in Nicotiana benthamiana confers Al tolerance. J Exp Bot 57:4235-4243

Diem B, Godbold DL (1993) Potassium, calcium and magnesium antagonism in clones of Popolus trichocarpa. Plant Soil 155(156):411-414

Ding Y, Luo W, Xu G (2006) Characterisation of magnesium nutrition and interaction of magnesium and potassium in rice. Ann Appl Biol 149:111-123

Dow AI, Roberts S (1981) Proposal: critical nutrient ranges for crop diagnosis. Agron J 74:401-403

Easterling DR, Meehl GA, Parmesan C, Changnon SA, Karl TR, Mearns LO (2000) Climate extremes: observations, modeling, and impacts. Science 289:2068-2074

Edmeades DC (2004) The magnesium requirements of pastures in New Zealand: a review. $\mathrm{N}$ Z J Agric Res $47: 363-380$
Edmeades DC, Wheeler DM, Blamey FPC, Christie RA (1991) Calcium and magnesium amelioration of aluminium toxicity in Al-sensitive and Al-tolerant wheat. In: Wright DC, Baligar VC, Murrmann RP (eds) Plant-soil interactions at low pH. Kluwer Academic Publishers, Dordrecht, pp 755761

Eghball B, Wienhold BJ, Gilley JE, Eigenberg RA (2002) Mineralization of manure nutrients. J Soil Water Conserv 57:470-473

Epstein E, Rains DW, Elzam OE (1963) Resolution of dual mechanisms of $\mathrm{K}$ absorption by barley roots. PNAS 49:684-692

Fageria NK (1973) Uptake of nutrients by rice plants from dilute solutions. Doctoral thesis, Catholic University of Louvain, Belgium

Fageria VD (2001) Nutrient interactions in crop plants. J Plant Nutr 24:1269-1290

Fageria NK (2009) The use of nutrients in crop plants. CRC Press, Taylor and Francis Group, London

Foy CD, Chaney RL, White MC (1978) The physiology of metal toxicity in plants. Annu Rev Plant Physiol 29:511567

Gardner RC (2003) Genes for magnesium transport. Curr Opin Plant Biol 6:263-267

Goss MJ, Carvalho MJGPR (1992) Manganese toxicity: the significance of magnesium for the sensitivity of wheat plants. Plant Soil 139:91-98

Gourley CJP, Allan DL, Russelle MP (1994) Plant nutrient efficiency: a comparison of definitions and suggested improvement. Plant Soil 158:29-37

Grimme H (1978) Wurzelsystem und Nährstoffanlieferung. Kali-Briefe 14:79-89

Grimme H (1991) Magnesium in landwirtschaftlichen und forstlichen Ökosystemen. KALI-BRIEFE 20:525-538

Grzebisz W (2011) Magnesium — food and human health. J Elem 16:299-323

Guo JH, Liu XJ, Zhang Y, Shen JL, Han WX, Zhang WF, Christie P, Goulding KWT, Vitousek PM, Zhang FS (2010) Significant acidification in major Chinese croplands. Science 327:1008-1010

Härdter R, Rex M, Orlovius K (2004) Effects of different Mg fertilizer sources on the magnesium availability in soils. Nutr Cycl Agroecosyst 70:249-259

Haug A (1983) Molecular aspects of aluminum toxicity. Crit Rev Plant Sci 1:345-373

Haynes RL, Naidu R (1998) Influence of lime, fertilizer and manure application on soil organic matter and soil physical conditions: a review. Nutr Cycl Agroecosyst 51:123-137

Hecht-Buchholz C, Schuster J (1987) Responses of Al-tolerant Dayton and Al-sensitive Kearney barley cultivars to calcium and magnesium during Al stress. Plant Soil 99:47-61

Hermans C, Verbruggen N (2005) Physiological characterization of Mg deficiency in Arabidopsis thaliana. J Exp Bot 56:2135-2161

Hermans C, Johnson GN, Strasser RJ, Verbruggen N (2004) Physiological characterization of $\mathrm{Mg}$ deficiency in sugar beet: acclimation to low magnesium differentially affects photosystems I and II. Planta 220:344-355

Hermans C, Bourgis F, Faucher M, Strasser RJ, Delrot S, Verbruggen N (2005) Magnesium deficiency in sugar beets 
alters sugar partitioning and phloem loading in young mature leaves. Planta 220:541-549

Horie T, Brodsky DE, Costa A, Kaneko T, Lo Schiavo F, Katsuhara M, Schroeder JI (2011) $\mathrm{K}^{+}$transport by the OsHKT2;4 transporter from rice with atypical $\mathrm{Na}^{+}$transport properties and competition in permeation of $\mathrm{K}^{+}$over $\mathrm{Mg}^{2+}$ and $\mathrm{Ca}^{2+}$ ions. Plant Physiol 156:1493-1507

Huang JW, Grunes DL (1992) Effects of root temperature and nitrogen form on magnesium uptake and translocation by wheat seedlings. J Plant Nutr 15:991-1005

Islam AKMS, Edwards G, Asher CJ (1980) pH optima for crop growth. Results of a flowing solution culture experiment with six species. Plant Soil 54:339-357

Jacoby B (1961) Calcium-magnesium ratios in the root medium as related to magnesium uptake by citrus seedlings. Plant Soil 15:74-80

Karley AJ, White PJ (2009) Moving cationic minerals to edible tissues: potassium, magnesium, calcium. Curr Opin Plant Biol 12:291-298

Keltjens WG, Tan K (1993) Interactions between aluminium, magnesium and calcium with different monocotyledonous and dicotyledonous plant species. Plant Soil 155(156):485-488

Kidson EB, Hole FA, Metson AJ (1975) Magnesium in New Zealand soils III. Availability of non-exchangeable magnesium to white clover during exhaustive cropping in a pot experiment. N Z J Agric Res 18:337-349

Kirkby EA, Knight AH (1977) Influence of the level of nitrate nutrition on ion uptake and assimilation, organic acid accumulation, and cation-anion balance in whole tomato plants. Plant Physiol 60:349-353

Klug B, Horst WJ (2010) Spatial characteristics of Al uptake and translocation in roots of buckwheat (Fagopyrum esculentum). Physiol Plant 139:181-191

Koc J, Szymczyk S (2003) Effect of agriculture intensity on the calcium and magnesium outflows from soils. J Elem 8:231238

Kopittke PM, Menzies NW (2007) A review of the use of the Basic Cation Saturation Ratio and the 'ideal' soil. SSSAJ 71:259-265

Koyama H, Toda T, Yokota S, Dawair Z, Hara T (1995) Effects of aluminium and $\mathrm{pH}$ on root growth and cell viability in Arabidopsis thaliana strain Landsberg in hydroponic culture. Plant Cell Physiol 36:201-205

Le Bot J, Goss MJ, Carvalho MJGPR, Van Beusichem ML, Kirkby EA (1990) The significance of the magnesium to manganese ratio in plant tissues for growth and alleviation of manganese toxicity in tomato (Lycopersicon esculentum) and wheat (Triticum aestivum) plants. Plant Soil 124:205-210

Lombin G, Fayemi A (1975) Release of exchangeable and nonexchangeable magnesium from Nigerian soils on cropping with maize or chemical extraction. J Sci Food Agric 27:101-108

Ma JF, Hiradate S, Nomoto K, Iwashita T, Matsumoto H (1997) Internal detoxification mechanism of $\mathrm{Al}$ in Hydrangea. Plant Physiol 113:1033-1039

Ma JF, Ryan PR, Delhaize E (2001) Aluminium tolerance in plants and the complexing role of organic acids. Trends Plant Sci 6:273-278

Maguire ME, Cowan JA (2002) Magnesium chemistry and biochemistry. BioMetals 15:203-210
Malcová R, Gryndler M, Vosátka M (2002) Magnesium ions alleviate the negative effect of manganese on Glomus claroideum BEG23. Mycorrhiza 12:125-129

Marschner H (2012) Mineral nutrition of higher plants. Academic, Elsevier

Marschner H, Kirkby EA, Cakmak I (1996) Effect of mineral nutrition status on shoot-root partitioning of photoassimilates and cycling of mineral nutrients. J Exp Bot 47:1255-1263

Matsumoto H, Hirasawa E, Morimura S, Takahashi E (1976) Localization of aluminium in tea leaves. Plant Cell Physiol 17:627-631

Mayland HF, Wilkinson SR (1989) Soil factors affecting magnesium availability in plant-animal systems: a review. J Anim Sci 67:3437-3444

Mehlich A (1948) Determination of cation- and anion-exchange properties of soils. Soil Sci 66:429-446

Mesić M, Kisić I, Bašić F, Butorac A, Zgorelec Ž, Gašpar I (2007) Losses of $\mathrm{Ca}, \mathrm{Mg}$ and $\mathrm{SO}_{4}{ }^{2-}$ with drainage water at fertilization with different nitrogen rates. Agric Conspec Sci 72:53-58

Mikkelsen R (2010) Soil and fertilizer magnesium. Better Crops 94:26-28

Mittler R (2006) Abiotic stress, the field environment and stress combination. Trends Plant Sci 11:15-19

Mokwunye AU, Melsted SW (1973) Magnesium fixation and release in soils of temperate and tropical origins. Soil Sci 116:349-362

Ortas I, Güzel N, Ibrikçi H (1999) Determination of potassium and magnesium of soils using different soil extraction procedures in the upper part of mesopotamia (in the Harran plain). Commun Soil Sci Plant Anal 30:2607-2625

Papenfuß KH, Schlichting E (1979) Bestimmende Faktoren des $\mathrm{Mg}$-Haushaltes von Böden in der Bundesrepublik Deutschland. Magnes Bull 1:12-14

Piechota T, Blecharczyk I, Malecka I (2000) Effect of long-term organic and mineral fertilization on nutrients content in soil profile. Fol Univ Agric Stein Agric 84:393-398

Rangel AF, Mobin M, Rao IM, Horst WJ (2005) Proton toxicity interferes with the screening of common bean (Phaseolus vulgaris L.) genotypes for aluminium resistance in nutrient solution. J Plant Nutr Soil Sci 168:607-616

Rice HB, Kamprath EJ (1968) Availability of exchangeable and nonexchangeable $\mathrm{Mg}$ in sandy coastal soils. SSSAJ 32:386-388

Römheld V, Kirkby EA (2007) Magnesium functions in crop nutrition and yield. Proceedings of a Confernce in Cambridge (7th Dec. 2007), 151-171

Salmon BC, Arnold PW (1963) The magnesium uptake under exhaustive cropping. J Agric Sci 61:421-425

Schachtschabel P (1954) Das pflanzenverfügbare Magnesium des Bodens und seine Bestimmung. J Plant Nutr Soil Sci 67:9-23

Scharrer K, Jung J (1955) Der Einfluß der Ernährung auf das Verhältnis von Kationen zu Anionen in der Pflanze. Z Pflanzenernähr Düngung Bodenkd 71:76-94

Scheffer F, Schachtschabel P (2002) Lehrbuch der Bodenkunde. Spektrum Akademischer Verlag, Heidelberg

Schroeder D, Zahiroleslam S, Hoffmann WE (1962) Untersuchungen über die Verfügbarkeit der Magnesiumvorräte des Bodens. Z Pflanzenernähr Bodenk 100:215-224 
Schubert S, Schubert E, Mengel K (1990) Effect of low pH of the root medium on proton release, growth, and nutrient uptake of field beans (Vicia faba). Plant Soil 124:239-244

Seggewiss B, Jungk A (1988) Einfluss der Kaliumdynamik im wurzelnahen Boden auf die Magnesiumaufnahme von Pflanzen. Z Pflanzenernähr Bodenk 151:91-96

Shabala S, Hariadi Y (2005) Effects of magnesium availability on the activity of plasma membrane ion transporters and light-induced responses from broad bean leaf mesophyll. Planta 221:56-65

Shaul O (2002) Magnesium transport and function in plants: the tip of the iceberg. BioMetals 15:309-323

Silva IR, Jot Smyth T, Israel DW, Rufty TW (2001) Altered aluminium inhibition of soybean root elongation in the presence of magnesium. Plant Soil 230:223-230

Staugaitis G, Rutkauskienè (2010) Comparison of magnesium determination methods as influenced by soil properties. Agriculture (Žemdirbystė) 97:105-116

Stevens G, Gladbach T, Motavalli P, Dunn D (2005) Soil Calcium:Magnesium ratios and lime recommendations for cotton. J Cotton Sci 9:65-71
Strebel O, Duynisveld WHM (1989) Nitrogen supply to cereals and sugar beet by mass flow and diffusion on a silty loam soil. Z Pflanzenernähr Bodenkd 152:135141

Sumner ME, Farina PMW, Hurst VJ (1978) Magnesium fixation - a possible cause of negative yield responses to lime applications. Commun Soil Sci Plant Anal 9:995-1007

Tan K, Keltjens WG (1995) Analysis of acid-soil stress on sorghum genotypes with emphasis on aluminium and magnesium interactions. Plant Soil 171:147-150

van der Pol, Traore B (1993) Soil nutrient depletion by agricultural production in Southern Mali. Fertil Res 36:79-90

Von Uexkull HR, Mutert E (1995) Global extent, development and economic impact of acid soils. Plant Soil 171:1-15

White JP, Broadley MR (2008) Biofortification of crops with seven mineral elements often lacking in human dietsiron, zinc, copper, calcium, magnesium, selenium and iodine. New Phytol 182:49-84

Zhang J, George E (2002) Changes in the extractability of cations $(\mathrm{Ca}, \mathrm{Mg}$ and $\mathrm{K})$ in the rhizosphere soil of Norway spruce (Picea abies) roots. Plant Soil 243:209-217 